\title{
NEW TENDENCY OF HIGHER EDUCATION DEVELOPMENT: THE FINLAND EXPERIENCE
}

\section{Movchan Liudmyla ${ }^{1}$}

DOI: https://doi.org/10.30525/978-9934-571-78-7_24

Abstract. The rapid development of society leads to changes in the level of economy and politics, and therefore requires new approaches to education. The processes of integration, globalization and technological innovation in the world have put new demands on the international labor market and modern society on the training of highly skilled experts. The tendency of Ukraine to enter the international educational space and socio-economic changes of recent years require modernization of the content of education based on the experience of higher education in foreign countries. The purpose of our study is to analyze the higher education system of Finland in order to use the progressive ideas of the Finnish experience in Ukraine. We used a set of interrelated theoretical and empirical methods of scientific research to achieve the stated goal. The methods of research are following: an interpretive-analytical method on the basis of which the study of Ukrainian and foreign sources was carried out using synthesis, analysis, systematization and generalization; empirical - observation of studying and training at the universities of Finland, interviews with teachers and government officials. Hundreds of delegations of policymakers and education specialists trek to Finland every year to learn from its experience first-hand. Many countries facing the learning crisis are also keen to find out what Finland has done to achieve good-quality learning for all. The Finnish higher education system is considered to be one of the best in the world: the enormous economic and scientific potential of this country is the result of a democratic system of education for citizens, significant expenditures on training and retraining, the use of modern pedagogical and information technologies, and technical means of training. The training of experts in the system of higher education in Finland is aimed at developing students' ability to set goals, independent study, creative thinking, teamwork, solve

${ }^{1}$ Candidate of Pedagogical Sciences,

Senior Lecturer at Department of Ukrainian and Foreign Languages,

Uman National University of Horticulture, Ukraine 
problems, make decisions and achieves the desired results. Universities of Finland teach critical thinking, analysis and selection of necessary facts among and endless sea of information. Finland's experience is useful for the higher education of Ukraine, as the Finnish education system meets the modern international educational standards; higher education institutions follow the needs of the labor market, accumulating the best world experience in the field of education, adapting it to the needs of its society.

\section{Introduction}

The global economic crisis affected almost every part of the world, every sphere of life, and higher education is no exception. The higher education system is closely linked to the economy, because the labor market annually receives new graduates who face the problem of employment. The employment problem makes graduates acquire new skills, and higher education establishments revise their curricula. The education system is developing in line with the labor market. The labor market in the new reality seems to be in a difficult situation as well. Higher education aims to fulfill multiple purposes; including preparing students for active citizenship, for their future careers (e.g. contributing to their employability), supporting their personal development, creating a broad advanced knowledge base and stimulating research and innovation $[8$, p. 5].

In a knowledge-based global economy, globalization increases interdependence and exerts influence between countries and between human communities on a global level which shape educational policies and practices which are fast becoming international rather than local. Trends in pressures on higher education institutions include the "rampaging" growth of knowledge itself, mass education, many more and different kinds of students, constraints on public funding, pressure to generate non-government sources of income, postgraduate demand for work-related specialist training, the emergence of new private providers, greater employer demand for suitably skilled graduates, and the growth of international markets for tertiary study $[4 ; 5 ; 10 ; 11]$.

Higher education, research and innovation play a crucial role in supporting social cohesion, economic growth and global competitiveness. Given the desire for European societies to become increasingly knowledgebased, higher education is an essential component of socio-economic and cultural development. At the same time, an increasing demand for skills and competences requires higher education to respond in new ways [8]. 
Broader access to higher education is an opportunity for higher education institutions to make use of increasingly diverse individual experiences. Responding to diversity and growing expectations for higher education requires a fundamental shift in its provision; it requires a more studentcentred approach to learning and teaching, embracing flexible learning paths and recognizing competences gained outside formal curricula. Higher education institutions themselves also become more diverse in their missions, mode of educational provision and cooperation, including growth of internationalization, digital learning and new forms of delivery $[1 ; 7]$.

Socio-economic changes in Ukraine lead to the need for modernization of the education system that would meet the actual requirements of the labor market. The Ukrainian higher education system is undergoing a transformation aiming to adapt it to the European and global education processes and to build a system which eventually ensures that graduates can compete not only in Ukraine but also in the European and international labour markets. In our opinion the use of the experience of foreign countries in the higher education system is an important condition for Ukraine's integration into the world educational space.

Ukrainian researchers who studied the professional training of experts from different countries of the world include: N. Abashkina (Germany), A. Vasyliuk (Poland), N. Vydyshko (Canada), V. Hrachov (Western Europe), T. Desiatov (Eastern Europe ), L. Liashenko (Finland), N. Mykytenko (Canada), Y. Neroba (Poland), L. Pukhovska (Western Europe), N. Sobchak (USA) and others.

The great source of studying the system of higher education abroad is the work of foreign scholars: C. Kerr, S. Marginson, P. Santiago, K. Trenblay, E. Barry, E. Arnel, A. Green, J. Spring.

The purpose of our study is to analyze the higher education system of Finland in order to use the progressive ideas of the Finnish experience in Ukraine. As the member of Nordic family Finland invested heavily and systematically in education. The general level of education has risen rapidly especially in the latter half of the 20th century.

\section{Finnish education in general}

One of the basic principles of Finnish education is that all people must have equal access to high-quality education and training. The same opportunities to education should be available to all citizens irrespective of 
their ethnic origin, age, wealth or where they live. The current thinking in Finland is that the potential of each pupil should be maximized. Therefore educational guidance is seen as essential. Guidance and counseling aims to support, help and guide pupils and students so that they can all perform as well as possible in their studies and be able to make correct and appropriate decisions concerning their education and careers. Guidance and counseling is seen as the work of all education personnel. Thus teachers are required to treat the children and young people as individuals and help them to proceed according to their own capabilities. Learners should also experience success and joy of learning. Today all pupils and students have the right to educational support. This support can be remedial instruction or support for the pupil's special needs.

In Finland the ideology is to provide special needs education primarily in mainstream education. If a pupil cannot be taught in a regular teaching group, he or she must be admitted to special needs education. This education is provided at regular schools wherever possible. All pupils of compulsory school age have the right to general support, that is, high-quality education as well as guidance and support. Intensified support must be given to those pupils who need regular support measures or several forms of support at the same time. The aim is to prevent existing problems from becoming more serious or expansive. If children cannot adequately cope with mainstream education in spite of general or intensified form of support, they must be given special support. The main purpose of special support is to provide pupils with broadly based and systematic help so that they can complete compulsory education and be eligible for upper secondary education. Special needs support is also provided in upper secondary education. In vocational education and training, students in need of special needs education are provided with an individual education plan. This plan must for example set out details of the qualification to be completed, the requirements observed and support measures provided for the student.

Finland has two official languages, Finnish and Swedish. Approximately five per cent of students in basic and upper secondary education attend a school where Swedish is the language of instruction. Both language groups have their own institutions also at higher education level. In addition there are educational institutions where all or at least some instruction is provided in a foreign language, most commonly in English. 


\section{Movchan Liudmyla}

Local authorities are also required to organize education in the Sami language in the Sami speaking areas of Lapland. Care is taken to ensure educational opportunities for Roma and other minorities as well as for people who use sign language. Education providers can for example apply for additional funding for organizing instruction in the official national languages for Roma, Sami and migrant children and for instruction in the pupil's mother tongue. Education providers also organize preparatory education for immigrants to enable them to enter basic or upper secondary education.

The Finnish education system has no dead-ends. Learners can always continue their studies on an upper level of education, whatever choices they make in between. The practice of recognition of prior learning has been developed in order to avoid unnecessary overlapping of studies. Finland has a long history of participation and promotion of adult education. The first Finnish folk high school started in 1889 . Adult education is very popular, the participation rate is high also in international terms. The main objectives of adult education policy are ensuring the availability and competence of the labour force, providing educational opportunities for the entire adult population and strengthening social cohesion and equity. The objectives should support efforts to extend working life, raise the employment rate, improve productivity, implement the conditions for lifelong learning and enhance multiculturalism.

Educational institutions organize education and training intended for adults at all levels of education. Efforts have been made to make the provision as flexible as possible in order to enable adults to study alongside work. Adult education comprises education and training leading to a degree or certificate, liberal adult education and staff-development and other training provided or purchased by employers as well as labour market training, which is mainly targeted at unemployed people. Liberal adult education offers non-formal studies. It promotes personal growth, health and well-being by offering courses relating to citizenship skills and society and in different crafts and subjects on a recreational basis. In both general and vocational education, there are also separate educational institutions for adults. In vocational training competence based qualifications are specifically intended for adults. In higher education adults can study in separate adult education programmes offered by polytechnics. Higher education with a dual structure Higher education is offered by universities 
and polytechnics. Both sectors have their own profiles. Universities emphasize scientific research and instruction. Polytechnics, also known as universities of applied sciences, adopt a more practical approach. There is restricted entry to all fields of study. As applicant volumes outweigh the number of places available, universities and polytechnics use different kinds of student selection criteria. Most commonly these include success in matriculation examination and entrance tests.

Teaching is an attractive career choice in Finland. Thus the teacher education institutions can select the applicants most suitable for the teaching profession. For example the intake into class teacher education is only 10 per cent of all applicants. In subject teacher education the intake varies from 10 to 50 per cent depending on the subject. In vocational teacher education the intake is 30 per cent of the applicants.

Teachers in basic and general upper secondary education are required to hold a Master's degree. Also teachers in vocational education and training have to hold a higher education degree. The high level of training is seen as necessary as teachers in Finland are very autonomous professionally. Teaching and guidance staff within day-care centres generally has Bachelor's degrees. Pre-primary teachers in schools hold Master's degree. Teachers in the first six years of basic education are usually generalists, class teachers, whereas those in the last three years and at upper secondary level are subject specialists, subject teachers. Class teachers have a Master's degree in education. Subject teachers have completed a Master's degree in the subject they teach as well as pedagogical studies. Depending on the institution and subject, vocational teachers are generally required to have an appropriate higher or postgraduate academic degree, an appropriate polytechnic degree or the highest possible qualification in their own vocational field. In addition at least three years of work experience in the field and completed pedagogical studies are necessary.

Guidance counsellors in basic and upper secondary education and training support pupils or students in their studies and any possible learning problems. The qualification requirements are a Master's degree and guidance counsellor studies. Special needs teachers help learners who have more serious problems both in mainstream education or special needs education. They also support and consult teachers. Special needs teachers hold a Master's degree with special pedagogy as the main subject or a teacher qualification including special needs teacher studies. Teachers 
at polytechnics are required to have either a Master's or a post-graduate Licentiate's degree, depending on their position. They must also complete pedagogical studies. University teachers are generally required to hold a Doctoral or other postgraduate degree.

Responsibility for the operations of basic education schools and upper secondary schools rests with principals. Principals are generally required a higher academic degree and teaching qualifications. In addition, they are required to have appropriate work experience and a certificate in educational administration or the equivalent. University rectors must hold a doctorate or a professorship. Most commonly the rector is appointed from among the professors of the university. In polytechnics, rectors are required a postgraduate Licentiate's degree or doctorate and have administrative experience.

At most levels of education the teachers are required to participate in in-service training every year as part of their agreement on salaries. Finnish teachers consider in-service training as a privilege and therefore participate actively. The State also provides in-service training programmes, primarily in areas important for implementing education policy and reforms. The education providers can also apply for funding to improve the professional competence of their teaching personnel. Teachers are recognized as keys to quality in education. Therefore continuous attention is paid to both their pre-service and continuing education [2].

\section{Higher education in Finland}

The history of Finland led to higher education and educational research being strongly influenced by a powerful nation-state until the late 1980s. A comparative study of higher education and research in the USA and Western Europe concluded that higher education systems in the Nordic countries have in many ways been the inverted image of those in the US. Finnish higher education has long been characterized by:

- relatively small size and restricted markets;

- strict centralization and control of resources;

- formal institutional uniformity with no hierarchy ostensibly recognized;

- restricted competition, exercised with respect not to markets, students, nor business but to state-controlled resources;

- low institutional initiative, as conditions of strict centralization inhibited the taking of initiatives, the challenge of bureaucratic rule in the universities or the development of an entrepreneurial spirit; 
- the right to study in higher education free of charge;

- strong belief in fostering social equality by removing the obstacles preventing equality of educational opportunities in higher education.

It took a considerable time for the Finnish university to be grafted onto the educational system and become part of wider social, economic and educational policy. For a long time, it remained an ivory tower dominated by the professorial body and the elite itself. It was only in the 1960s that the growing welfare state, through the rising Ministry of Education, began to legislate, regulate and plan more powerfully the of "massification" of the higher education system.

Today, the trend in Finland is to promote all kinds of competitiveness and effectiveness. An increasingly unequal division of resources has become more than a rule as it is considered desirable to favour "diversity" and "giftedness" and to open up new pathways for the best human capital and centres of excellence, i.e. for those with special gifts and inclinations. The universities are marching in the front ranks of the new "policy of assessment". Following closely in their footsteps are all the educational levels, from primary school up to adult education [9, p. 23-42].

The Finnish Matriculation Examination provides general eligibility for higher education. In addition, those with a post-secondary level vocational qualification or at least a three-year vocational qualification have general eligibility for university education. Universities may also admit applicants, who are otherwise considered to have the necessary skills and knowledge to complete the studies. At universities students can study for Bachelor's and Master's degrees and scientific or artistic postgraduate degrees, which are the Licentiate and the Doctorate degrees. In the two-cycle degree system students first complete the Bachelor's degree, after which they may go for the Master's degree. As a rule, students are admitted to study for the Master's degree. The target time for taking a Master's degree is generally 5 years. The average time for taking a Master's degree in Finland is, however, six years. The policy-makers have introduced several measures to shorten graduation times and increase completion of studies, including personal study plans and financial incentives, for example.

The general requirement for admission to polytechnics is completion of general upper secondary education or vocational education and training. Student selection to polytechnics is mainly based on entrance examinations, school achievement and work experience. Polytechnics may also admit 
applicants who are otherwise considered to have the necessary skills and knowledge to complete polytechnic studies. Degree studies at polytechnics give a higher education qualification and practical professional skills. They comprise core and professional studies, elective studies and a final project. All degree studies include practical on-the-job learning. The extent of polytechnic degree studies is generally 210-240 ects points, which means 3-4 years of full-time study. It is further possible to take a polytechnic Master's degree after acquiring a minimum of three years' work experience. The polytechnic Master's takes 1.5-2 years, and is equivalent to a university Master's degree.

The Finnish higher education system is divided into two parallel sectors: universities and universities of applied sciences. Universities concentrate on academic and scientific research and education whereas universities of applied sciences are more oriented towards working life and its standards.

The network of higher education institutions includes 14 universitylevel institutions ( 9 comprehensive research universities, 2 more specialized multidisciplinary universities, 2 universities of technology, and a school of business and economics) and 26 universities of applied sciences.

These institutions are conforming to the European-wide Bologna process of reform in which typically the first university degree requires 3 years of study and the masters level degree takes 2 years to earn.

Study programs are organized according to a module plan and course assessments provided in the ECTS system. Many masters level programs are now available in English, opening programs to more international students from around the world, including large numbers of European students participating in the various EU mobility and exchange programs. Instruction at institutions of higher education is free of charge for degree students (with some exceptions). At the moment some Finnish higher education institutions are piloting tuition fees for some Master's degree programs for non-EU/EEA nationals.

Bachelor's and Master's students pay a small membership fee to their institution's student union every year (this fee is not mandatory for universities of applied sciences). In return, they get reduced-price meals, health care services and other social benefits. Students are eligible for higher education when they have passed the matriculation examination or received a vocational qualification. Students nationwide apply to institutes of higher education using the electronic system maintained by the National Board of Education [2]. 


\section{University reform (2010)}

Universities are nowadays expected to show results: creative, productive scientific work; scientific discoveries and breakthroughs; and the training of professionals with a state-of-the-art command of their fields. In order to ensure that universities fulfil their goals in terms of efficiency, creativity and productivity, European governments are increasingly resorting to a new strategy of self-regulation under which universities are given increased autonomy in order to create a fertile basis for creative and productive operations [6].

Finland government in 2010 set some act in order to improve education system in the country [3]. The Universities Act (558/2009) includes provisions on the mission, administration, operational funding and steering of universities, and matters relating to research and education, students and personnel; universities became legal persons separate from the State, either as corporations under public law or foundations under the Foundations Act; Universities took the place of the State as employers; The Ministry of Education and Culture ensures by means of steering that university activities conform to the higher education policy aims set by Parliament and the Government; Lighter and more strategic level performance agreement procedure between MoE and universities; Evaluated 2012 - short term results of the evaluation indicate improvements especially in strategic, economic and internal management and in co-operation with surrounding society. Aims of the university reform:

- greater autonomy;

- stronger financial and administrative status: independent legal persons and supplied with sufficient capital;

- greater latitude with finances: donations, income from capital and business activities;

- as legal persons, the universities are better able to operate with the surrounding society;

- having their own capital, the universities will have more scope for operating based on their own decisions;

- stronger community relations - e.g. external members of the board.

Reform did not change: the freedom of research, art and education; selfgovernment and academic decision-making; research and higher education remain as the main tasks of the universities; education leading to a degree free of charge; the government continues to be responsible for funding the public duties of the universities. 


\section{Movchan Liudmyla}

Aims of the polytechnic reform:

- as independent legal persons polytechnics will have more independent status and more flexibility to better react and response to the needs of the surrounding society;

- stronger strategic competence, profiling, focus area choices, stronger leadership and ability to decision making;

- to enhance the quality and effectiveness of teaching and RDI;

- to strengthen their role within the system of innovation;

- to ensure international competitiveness of the polytechnic system.

First phase of the reform (2014): new funding model, new operating licenses, updated educational responsibilities. Second phase of the reform (2015): the polytechnics and the organisations running them to merge into one legal person, and juridically all the polytechnics became limited companies; the responsibility for core funding entirely transferred to the state.

Structural reforms: merger of research institutes, development of activities of research consortiums, merger of research institutes with the University of Helsinki, deeper co-operation between research institutes and universities.

Research funding reforms:

- establishment of a strategic research funding instrument;

- strengthening research, assessment activity and report work in support of decision-making by the government;

- gathering of research funding from ministries;

- new professional specialization studies in universities and polytechnics;

- from the beginning of 2015, new type of education alongside degree studies and continuing education;

- the reform aims at providing flexible opportunities for adults to upgrade their competencies and expertise at the higher education level, also to reduce multiple degree studies;

- for those with HE qualification and some work experience;

- to be based on the needs of working life and the R\&D competence of universities and polytechnics;

- decisions on professional specialization studies are made by universities and polytechnics, in concordance with their educational responsibilities -majority decision;

- in decision making cooperation with the representatives of working life is required;

- minimum 30 study credits; 


\section{Chapter «Pedagogical sciences»}

- maximum tuition fee 120 euros/study credit. (Ministry of Education and Culture).

Since the beginning of 2018 , the vocational education and training reform in Finland has made it possible to export vocational qualifications. The most interesting educational products for potential buyers are qualifications in entrepreneurship, management, metal work and machinery, the processing industry, social and health care, electrical engineering and automation technology, engineering, and product development [3].

\section{Universities of Applied Sciences (UAS)}

During the 1990s Finnish higher education underwent a thorough change with the emergence of the universities of applied sciences (ammattikorkeakoulu), formerly called polytechnics. The universities of applied sciences were formed by upgrading and merging the specialized institutions which offered vocational higher education. The universities of applied sciences emphasize close contacts with business, industry and services, especially at the regional level, and the education has a pronounced occupational emphasis. They train professionals in response to labor market needs.

The universities of applied sciences carry out some R\&D with a distinctly applied and practical emphasis, whereas scientific research is the mandate of the universities. They also conduct research and development, which supports instruction and promotes regional development in particular. UAS institutes are owned by either municipalities or by private entities. They also, however receive funding from the Ministry of Education.

Like university education, UAS education is also divided into the Bachelor's and Master's levels. UAS students often have to complete a three-year work experience requirement before they can apply to a UAS Master's degree program. Students with a Bachelor's degree from a UAS may also apply to a Master's program at a university, although they are often required to take additional courses. Each student has a personal study plan, which facilitates student guidance and the monitoring of progress in studies. Universities of applied science also arrange adult education and open education geared to maintain and upgrade competencies.

Satakunta University of Applied Sciences (SAMK) is located on the west coast of Finland, in the Satakunta region. There are about 6,300 students in total and more than 250 international students studying on its campuses every year. 


\section{Strategic goals:}

1.International education and research: Persistent internationalization is a steering force in changing and developing education and research. Over 20 per cent of intake will be targeted to English language degree programmes, and the volume of education export will exceed 0.5 million euros. In addition, more than 50 per cent of the projects consist of international projects. Each emerging area has at least two experts with international regard.

2.Learning environments students appreciate: Teaching and learning are improved by SAMK's new facilities, laboratories and learning environments. Entrepreneurial operating environments and digital teaching create new ways of learning. The new curricula are characterized by practice-based, work-related studies and a variety of collaboration forms with the employment market. In the feedback SAMK is one of the best three in regard to learning environments.

3. Centre of collaboration in the employment market: Competence and expertise clusters with education, research and entrepreneurial activities are constructed around SAMK campuses. SAMK acts as an engine for thematic innovation environments and development networks as well as international strategic centres of expertise. Each student completes at least 20 ECTS in work settings and practical tasks (in addition to thesis work and practical training).

4. Higher education community with competent and thriving staff: Competent and thriving staff guarantees quality, effectiveness and development at SAMK. Competences are developed systematically with long-term goals and by strategic decisions. The indexes describing staff competences and well-being at work are higher than in expert organizations on average. In the feedback SAMK is one of the best three in regard to studies.

5. Leeway provided by effective functions: SAMK's functions are based on smooth progress of studies and graduations as scheduled. Effective functions are supported by succeeding in applying national and international complementary funding. The amount of complementary funding increases annually with an intermediate goal of 4 per cent. The financial statement is positive every year.

6. Attitude: All SAMK employees are responsible for the success of SAMK. As a result, they should be enthusiastic and open towards students, 
clients and colleagues. We build future together and therefore it matters what we do and what we do not do. Workers in SAMK want to excel. The index value describing well-being at work is higher than in expert organizations in general.

SAMK is a multidisciplinary higher education institution, which offers both Bachelor's and Master's degrees in the fields of construction and energy, health, ICT, logistics and maritime technology, service business operations and welfare. It has campuses in the biggest cities in the region: Pori, Rauma, Kankaanpaa and Huittinen offer spacious and safe living conditions, a lot of green nature and excellent opportunities for leisure activities. The cities are big enough to offer all the necessary services but also small enough to have a cozy and friendly atmosphere. Fields of education: Arts and Design; Business; Computer Science and Information Technology; Engineering and Technology; Health Care and Social Services; Tourism and Catering. Bachelor's degree programmes in English: International Business; Physiotherapy; Industrial management; Logistics; Nursing; Sea Captain; Tourism. Master's degree programmes in English: Business Management and Entrepreneurship; Information Technology, Maritime Management, Rehabilitation, Welfare Technology.

Degree Programme in International Tourism Development.

The entrance examination consists of three parts: 1. Logicalmathematical test 2. Material-based exam 3. Motivational video. Logical mathematical test measures applicant's logical skills, mathematical skills and understanding of written English. Each applicant has 1,5 hours to complete the exam after starting it. Applicant is required to get at least 16 points out maximum 40 points from this section. In the material-based exam, applicant is required to answer questions based on material about international tourism. Material is given on the exam platform either when it's opened or during the exam. In the motivational video, applicant should be able to bring up issues about the exam material using his/her own computer, webcam, headset/microphone and Internet connection. Both parts will be instructed to eligible applicants before the examination opens, and both parts will be time-limited inside the examination open period. There will be more detailed information in Studyinfo.fi about the examination. Applicant is required to get at least 24 points out maximum 60 from this section [12]. 


\section{University education}

The mission of universities is to conduct scientific research and provide undergraduate and postgraduate education based on it. Universities promote free research and scientific and artistic education, provide higher education based on research, and educate students to serve their country and humanity.

Undergraduate education in Finland is divided into two tiers: Bachelor's and Master's. The Bachelor's degree usually lasts between three and four years. After that, students generally pursue a two-year Master's degree, very often at the same institution. After graduating from the Master's level (which includes a Master's thesis), students can apply for post graduate studies ('graduate studies' refer to Master's level studies in Finland, whereas 'postgraduate' refers to Licentiate and Doctorate level). The two levels of postgraduate studies are Licentiate and Doctorate.

Beyond the master's degree, one can study for the licentiate degree (lisensiaatin tutkinto), a sort of junior doctorate, and upon defense of a dissertation the licentiate holder may be awarded a doctorate (tohtorintutkinto). The licentiate, however, is quite rare. In most fields of study, it is also possible to start working for a doctorate directly after completing a master's degree. Studies toward the licentiate or doctorate are mostly of an independent nature. Traditionally, there have been few organized doctoral programs resembling those in American academia, but researcher training is currently undergoing major changes in Finland and the number of such programs is on the rise.

Studies at Finnish universities are very independent. Even at the Bachelor's level, students are responsible for their own study plans, and have a high degree of flexibility when it comes to planning when they will take the various courses and exams that make up their degree.

In relation to population, Finland has one of the most comprehensive university networks in Europe. Geographically, the network covers the whole country. Overall, there are approximately 170,000 students in university education, of whom 21,900 are postgraduate (post Master's) students.

The courses of study are rigorous and admission is difficult: only ten percent of each senior secondary graduating class will gain university admission. On the other hand, there are no tuition fees except in some International programs (usually taught in English), MBA and LLM courses, etc., and students are eligible for government financial aid and some grants. 
Due to the structure of the Finnish university system, students are relatively free to determine the rate and direction of their courses of study. Many courses may be passed by readings and examinations on prescribed books in lieu of lecture attendance. Moreover, both course and departmental examinations may be retaken several times [2].

The University of Helsinki is the leading versatile research university in Finland continuously ranking in the world's top 100 . The high-quality research carried out by the university creates new knowledge for educating diverse specialists in various fields, and makes a solid foundation for social decision-making and successful operations in the business sector. The university, with 35,000 students and almost 5,000 researchers and teachers, operates on four campuses in Helsinki. Founded in 1640, the University of Helsinki wants to strengthen its position among the world's leading multidisciplinary research universities and to actively promote fair society and the wellbeing of humanity.

The University of Helsinki seeks solutions for global challenges and creates new ways of thinking for the best of humanity. Through the power of science and research, the University has contributed to society, education and welfare since 1640 . They have educated nine presidents and thousands of people at the top of politics, science, culture and economics. Not to mention four Nobel prize winners.

Fields of education: Agriculture and Forestry; Dentistry; Economics; Educational Sciences; Humanities; Law; Medicine; Natural Sciences; Pharmacy; Psychology; Social Sciences; Theology; Veterinary Medicine.

Master's Degree programmes in English:

1.Humanities, Social Sciences and Law: Democracy and Global Transformations; Economics; Economy, State and Society (Erasmus Mundus); Education, Diversities and Social Justice; Ethnic Relations, Cultural Diversity and Integration; European Studies; Intercultural Encounters; International; Business Law and Public International Law; Media and Global Communication; Religious Roots of Europe; Religion, Conflict and Dialogue.

2. Science and Technology: Advanced Spectroscopy in Chemistry; Atmosphere Studies; Computer Science; Chemistry; Geography and Geology; Mathematics and Applied Mathematics; Statistics; Physical Sciences. 
3.Life Sciences: Biology; Biotechnology; Environment and Natural Resources; Environmental Sciences; Food Sciences; Forest Sciences and Business; Molecular Biosciences; Neuroscience; Plant Production Science; Translational Medicine.

Doctoral Degree programmes in English: All doctoral programmes at the University of Helsinki can be carried out in English. The Doctoral School in Environmental, Food and Biological Sciences, the Doctoral School in Health Sciences, the Doctoral School in Humanities and Social Sciences and the Doctoral School in Natural Sciences offer a total of 32 doctoral programmes.

Faculty of Agriculture and Forestry: the goal is to promote sustainable production as well as sustainable use and consumption of renewable resources. They focus on agricultural and forest sciences, food and nutrition, microbiology, as well as environmental and resource economics. The Faculty of Agriculture and Forestry offers the following degree programmes:

- Bachelor of Food Sciences or Bachelor of Science (Agriculture and Forestry);

- Master of Food Sciences or Master of Science (Agriculture and Forestry);

- Licentiate of Food Sciences or Licentiate of Science (Agriculture and Forestry);

- Doctor of Food Sciences or Doctor of Science (Agriculture and Forestry).

The Bachelor's degree is a first-cycle and the Master's degree a second-cycle academic degree. Licentiate and doctoral degrees are postgraduate research degrees (third-cycle academic degrees). Bachelor's (undergraduate) studies and Master's programme in Food Economy and Consumption are available only for applicants with good Finnish or Swedish language skills. The application period for these programmes is during the general application in spring. The application period for multiand foreign-language Master's programmes starts in December and ends in January. In the future, education will be open to all, communal and centred on students. At the University of Helsinki, the future of education is already becoming a reality. The competence of the University's pedagogical experts is based on knowledge, research and practical teaching. The teachers are offering a new way of thinking for the entire educational sector [13]. 


\section{Conclusions}

Finland has one of the most respected national education systems and brands in the world. Thanks to its performance in many international comparisons there has been an ever-increasing global interest in the Finnish education system and its various aspects. The basic education system in Finland today is a result of many decades of development and reform. Importantly, education enjoys strong support from the entire society. Parents also see education as the way to economic opportunities and better life for their children. Since the 1960s, school reforms have been based on values of equity and equal opportunity - universality and high-quality education for all. These reforms have achieved their objective: variation between individual students and between schools is smaller than in most other PISA countries.

The Finnish believe that learning is the only way towards a sustainable future. Everyone needs to have wisdom and knowledge, and everyone has the right to learn. Lifelong learning, the openness of learning, digitalisation, collaboration between higher education institutions and upper secondary school students, certificate-based admission and alternative paths - a lot is going on in the field of adult and higher education at the moment. Changes in the world and professional life will only increase the significance of learning, in terms of both individuals and society, even of the entire world and its future. Education increases well-being, reduces marginalisation, promotes sustainable development and impacts economic growth.

\section{References:}

1. Communication from the European Commission: Opening up Education: Innovative teaching and learning for all through new Technologies and Open Educational Resources. (2013). 654 final. URL: http://ec.europa.eu/education/ news/doc/openingcom_en.pdf

2. Higher education in Finland.URL: http://www.fulbright.fi/en/guide/highereducation)

3. Higher education in Finland. Ministry of education and culture. Department for Higher education and science policy. URL: https://minedu.fi/en/heis-andscience-agencies

4. Kerr, C. (2001). The uses of the university (5th ed.). Cambridge: Harvard University Press.

5. Marginson, S. (2008, November). Global, multiple and engaged: Has the "idea of a university" changed in the era of the global knowledge economy? Fifth international workshop on higher education reforms, East China Normal University. 


\section{Movchan Liudmyla}

6. Neave, G. 1990. "On preparing for markets: trends in higher education in Western Europe, 1988-1990". European Journal of Education, 25(2), 105-122.

7. Pamela A. Norman. (2014, May). Achiving internationally recognized academic standards of quality. Contemporary PNG Studies: DWU Research Journal, 20, 18.

8. Recommendation Rec (2007). by the Council of Europe's Committee of Ministers on the public responsibility for higher education and research. URL: http://www.coe.int/t/dg4/highereducation/News/pub_res_EN.pdf

9. Rinne, R., Kivinen, O. (2000). The Nordic welfare state model and European Union educational policies. P. Rasmussen (Ed): Educational policy and the global social order, 34.

10. Santiago, P., Trenblay, K., Basri, E. and Arnal, E. (2008a). Executive summary: Tertiary education for the knowledge society. Paris: OECD, 1, 13-22.

11. Santiago, P., Trenblay, K., Basri, E. and Arnal, E. (2008b). Assuring and improving quality, tertiary education for the knowledge society. Paris: OECD, 1, 259-317.

12. Satakunta University of Applied Sciences (SAMK). URL: http:www.samk.fi/ English

13. University of Helsinki. URL: http:Helsinki.fi/studying 